\title{
Sources of microbial contamination in the watershed and coastal zone of Soufriere, St. Lucia
}

\author{
Marsha Serville-Tertullien $\cdot$ Kareem Charlemagne $\cdot$ Newton Eristhee $\cdot$ \\ Kevin McDermott • Anna Majury • Timo Schirmer • Tamanna Sultana • \\ Chris D. Metcalfe
}

Received: 15 July 2021 / Accepted: 5 February 2022 / Published online: 26 February 2022

(C) The Author(s), under exclusive licence to Springer Nature Switzerland AG 2022

\begin{abstract}
The Sustainable Development Goal 6 calls for global progress by 2030 in treating domestic wastewater and providing access to adequate sanitation facilities. However, meeting these goals will be a challenge for most Small Island Developing States, including Caribbean island nations. In the nearshore zone of the Soufriere region on the Caribbean island of St. Lucia, there is a history of high levels of bacteria of fecal origin. Possible land-based sources of microbial contamination in the Soufriere Bay include discharges from the Soufriere River and transport of wastewater, including fecal material from the town
\end{abstract}

Supplementary information The online version contains supplementary material available at https://doi. org/10.1007/s10661-022-09862-4.

M. Serville-Tertullien $(\varangle) \cdot$ T. Sultana $\cdot$ C. D. Metcalfe School of the Environment, Trent University,

Peterborough, ON, Canada

e-mail: marshaserville@trentu.ca

K. Charlemagne $\cdot$ N. Eristhee

Caribbean Public Health Agency (CARPHA), Castries,

St. Lucia

K. McDermott · A. Majury

Public Health Ontario, Kingston, ON, Canada

T. Schirmer

Deutsche Gesellschaft Für Internationale Zusammenarbeit (GIZ), Bonn, Germany

T. Schirmer

AFRY Deutschland GmbH, North Rhine-Westphalia, Essen, Germany of Soufriere. This area is an important tourist destination and supports a local fishery. To identify the sources of microbial contamination in Soufriere Bay, a range of monitoring methods were employed in this study. In grab samples of surface water collected from the Soufriere River, counts of total coliforms and Escherichia coli were elevated above water quality guidelines. However, the spikes in concentrations of these indicator organisms in the river did not necessarily coincide with the spikes in the levels of total coliforms and E. coli detected in samples collected on the same dates in Soufriere Bay, indicating that there are other sources of pollution in the Bay besides discharges from the river. Monitoring for chemical indicators of wastewater (i.e., caffeine, sucralose, fluconazole) in the Soufriere River indicated that there are inputs of sewage or human fecal material throughout the watershed. However, analysis of Bacteroidales 16S rRNA genetic markers for fecal bacteria originating from humans, bovine ruminants, or other warmblooded animals indicated that the majority of microbial contamination in the river was not from humans. Monitoring for chemical indicators of wastewater using passive samplers deployed in Soufriere Bay indicated that there are two "hot spots" of contamination located offshore of economically depressed areas of the town of Soufriere. This study indicates that efforts to control contamination of Soufriere Bay by fecal microorganisms must include management of pollution originating from both sewage and domestic animals in the watershed. 
Keywords Caffeine $\cdot$ Sucralose $\cdot$ E. coli $\cdot$ Total coliforms $\cdot$ Bacteroidales $\cdot$ Wastewater

\section{Introduction}

It has been estimated that $85 \%$ of wastewater entering the Caribbean Sea is either untreated or poorly treated (Cashman, 2013). Results of a survey conducted in 2000 by the Pan-American Health Organisation indicated that about half of the households in Caribbean countries lack a sewer connection and only $17 \%$ are connected to an adequate treatment system (PAHO, 2001). Barriers to improving wastewater management in the Caribbean include a lack of financial resources, inadequate regulatory frameworks, fragmented responsibility for wastewater management, limited technical and operational capacity, and a lack of awareness of alternative low-cost treatment technologies (UNEP-CEP, 2010). The Sustainable Development Goal 6 calls for global progress by 2030 towards improving wastewater treatment and providing adequate sanitation facilities. However, significant challenges exist among Caribbean nations in meeting the targets for this goal (ECLAC, 2019; Malik et al., 2015).

Adequate wastewater management is a challenge on the island of St. Lucia, as it is for most Small Island Developing States (SIDS). Point and non-point sources of sewage are significant contributors to pollution in the coastal zone near small and larger urban centers along the coasts. The town of Soufriere on the southwest coast of St. Lucia has been the focus of concerns regarding impacts of coastal pollution on public health, the tourism sector, artisanal fishery, and associated livelihoods. The nearby Pitons Management Area was designated as a World Heritage Site in 2004 by the United Nations Environment Scientific and Cultural Organisation and so the environmental sustainability of the town of Soufriere is critical to its success as a tourist destination. The Soufriere Marine Management Area (SMMA) stretching along the coast is important for sustaining an artisanal fishery, recreational diving and snorkeling, and other marinebased pursuits. However, in a report on the wastewater infrastructure in Soufriere released in 2006, it was recognized that no centralized sewage treatment system exists in the community (CEHI, 2006). Pit latrines and septic tanks with soakaway pits are the most common sanitary systems, and these "continue to be a main source of direct or indirect pollution of the marine environment as a result of design and construction flaws" (CEHI, 2006). Since the publication of this report, there has been little progress made in addressing the recommendations in the report to improve wastewater management in the community.

The marine environment of Soufriere Bay is also impacted by land-based sources (LBS) of pollution released into the coastal zone by the Soufriere River. The Forests and Lands Resources Department in St. Lucia classified the Soufriere watershed as a priority location for implementing a watershed management plan because of its vulnerability and significance in the provision of ecosystem services, including supplying water for the town of Soufriere (Saint Lucia Forests \& Lands Resources Department, 2015). The $16-\mathrm{km}^{2}$ mixed-use watershed is being rapidly cleared of natural forest cover to make way for housing, tourism developments, farms, and road networks. The contributions of the watershed to LBS pollution increase during the annual rainy season from June to November, and climate change may be increasing the frequency and intensity of extreme weather events. This LBS pollution has implications for human health in the town of Soufriere and also for the health of flora and fauna in the marine receiving waters (Bégin et al., 2014; Pittman et al., 2015).

In 2010, the Soufriere watershed was heavily impacted by Hurricane Tomás and flooding and landslides caused major damage to the natural environment and infrastructure, as well as loss of life. A survey of microbial contamination of surface waters conducted in late October before the hurricane and in mid-November after the hurricane showed that prehurricane, there were high counts of total coliforms, fecal coliforms, Enterococci, and Escherichia coli (E. coli) detected at several monitoring locations within the Soufriere watershed and along the coastal zone of Soufriere Bay, and these counts increased 100-fold after the hurricane (Caribbean Ecohealth Programme, unpublished data). The watershed remains severely damaged and eroded to this day and there are ongoing inputs of suspended sediments, nutrients, and microbial pathogens.

The US Environmental Protection Agency (US EPA) recommends using $E$. coli to detect fecal contamination in recreational waters, but there are several limitations to using E. coli as a marker of 
pollution originating from sewage. E. coli has been detected in pristine tropical environments (Bermudez et al., 1988), and is present in the intestinal tract of all warm-blooded animals, not just humans (Wade et al., 2015). Since traditional microbial indicators cannot discriminate between fecal contamination from humans and warm-blooded domestic and wild animals, several studies have explored using other source-specific indicators of pollution. Chemical detection methods offer several advantages over monitoring for microbial indicators. Pharmaceuticals and compounds present in foods and beverages that are excreted by humans into sewage have been shown to be reliable indicators of wastewater contamination (Daneshvar et al., 2012; Tran et al., 2015; Wade et al., 2015). Quantitative polymerase chain reaction (qPCR) techniques applied to microbial source tracking (MST) make it possible to identify fecal bacteria that are specific to humans and to domestic animals (Tran et al., 2015). Assays using RNA genetic markers for strains of Bacteroidales are particularly useful for these MST studies (Lee et al., 2010; Wade et al., 2015).

The objectives of this study were to evaluate levels of microbial contamination in Soufriere Bay and the Soufriere River and to identify sources of this contamination. In July of 2018, grab samples of water were collected at several locations within the
Soufriere River watershed for analysis of total coliforms, E. coli, chemical indicators of wastewater contamination, and genetic markers of Bacteroidales 16S rRNA. From February to May 2019, samples of surface water were collected in Soufriere Bay for analysis of counts of total coliforms and E. coli. Finally, passive samplers were deployed at five locations in the Soufriere River in July of 2018 and at five locations in Soufriere Bay in October of 2020 to monitor for levels of chemical indicators of wastewater contamination. Chemical indicator compounds included caffeine, an artificial sweetener added to foods and beverages (i.e., sucralose), and a pharmaceutical used to treat fungal infections in humans (i.e., fluconazole). Several other target pharmaceuticals were also monitored in the passive samplers deployed in Soufriere Bay in 2020.

\section{Methods and materials}

\section{Sampling}

\section{MST in the Soufriere River}

Monitoring sites in the Soufriere River watershed are illustrated in Fig. 1. These sites included Soufriere at Palmiste Road (R1), Soufriere at New Development
Fig. 1 Monitoring sites within the Soufriere River (red dots) and within Soufriere Bay (blue dots) located in the southwestern part of the Caribbean Island of St. Lucia (inset)

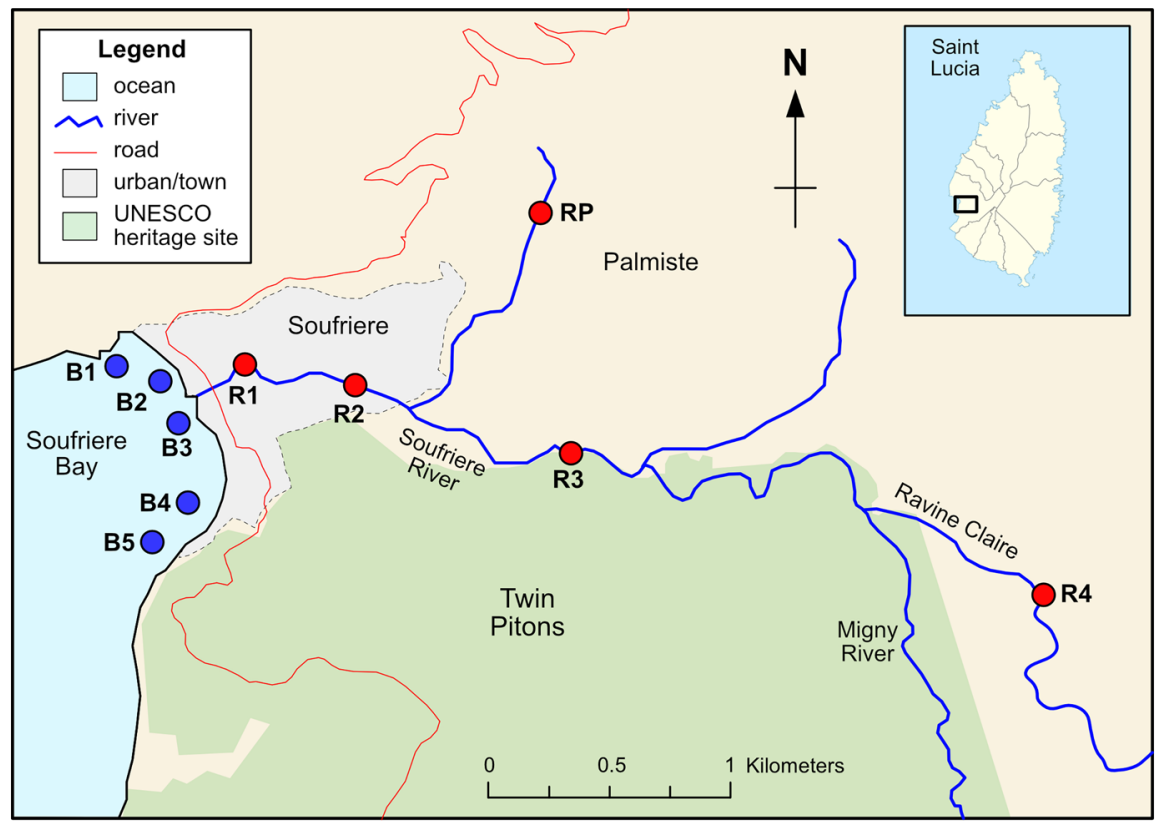


Bridge (R2), Cressland (R3), Ravine Claire bridge (R4), and Ruby Estate in Palmiste (RP). Monitoring was conducted by collecting grab samples of water at sites R1, R3, and R4 on July 4th and July 17th, 2018 for analysis of microbiological indicator organisms and chemical indicators of wastewater contamination. In addition, the passive sampling devices, Polar Organic Chemical Integrative Samplers (POCIS), were deployed at all five sites to monitor for chemical indicators of wastewater. POCIS were deployed in cages ( $n=3$ per cage) at the five sites within the watershed for a period of 13 days between July 4 and 17, 2018. POCIS were anchored in the river by attaching the cages to iron stakes driven into the substrate. Two POCIS were also exposed to the air during deployment and retrieval, as field blanks.

\section{Survey of microbial indicators in the Soufriere River and Soufriere Bay}

Over the period between February and May of 2019, grab samples of surface water were collected within Soufriere Bay and in the Soufriere River watershed. The dates of sampling were February 5, 13, 18, and 27; March 5, 12, 21, and 26; April 2 and 10; and May 7 and 21 . On the same dates over the same period, grab samples were also collected from 10 locations within Soufriere Bay. These sampling sites were determined by selecting five nearshore locations and corresponding offshore locations approximately $120 \mathrm{~m}$ from the shoreline. The locations of the 19 sampling sites in the Soufriere River and Soufriere Bay are illustrated in supplementary Information in Fig. S2, and the GPS coordinates are listed in Table S2.

\section{Chemical indicator monitoring in Soufriere Bay}

Sites for monitoring in Soufriere Bay are also illustrated in Fig. 1. POCIS were deployed in cages $(n=3$ per cage) for a 2-week period from October 30th to November 13th in 2020 at five locations in the coastal zone. The cages were anchored to the bottom and suspended with buoys in the water column at a depth of approximately $5 \mathrm{~m}$ in the nearshore zone within the Bay. Water depths at all deployment locations were between 10 and $12 \mathrm{~m}$. POCIS deployment locations were named after the nearest land-based features, including Hummingbird Beach (B1), North
River Mouth (B2), South River Mouth (B3), Dock (B4), and Baron's Drive (B5). Two POCIS were also exposed to the air during deployment and retrieval as field blanks.

\section{Sample collection and storage}

All grab samples were collected in sterile 1-L Nalgene bottles (VWR International, Mississauga, ON, Canada) and immediately stored on ice in a cooler. Samples collected for microbiological analysis (i.e., total coliforms and E. coli) were subsequently refrigerated and analyzed within $48 \mathrm{~h}$. Samples for analysis of genetic biomarkers of fecal bacteria were refrigerated for a few hours and then shipped by overnight courier to the Public Health Ontario Laboratory in Kingston, ON, Canada. All grab samples for analysis of chemical indicators of wastewater were frozen and then were shipped on dry ice by courier to Trent University in Peterborough, ON, Canada, for extraction and analysis. Upon retrieval, POCIS were wrapped in aluminum foil and stored in a freezer at $-20{ }^{\circ} \mathrm{C}$, then shipped by courier to Trent University for processing and analysis.

\section{POCIS passive samplers}

POCIS containing Oasis ${ }^{\circledR}$ HLB sorbent were purchased from EST Labs (St. Joseph, MO, USA). Some POCIS that were spiked with Performance Reference Compounds (PRCs) were also prepared in the laboratory by spiking $200 \mathrm{mg}$ of sorbent powder with 0.4 $\mu \mathrm{g}$ of metoprolol-d6, placing the sorbent between two polyether sulfone membranes and assembling the POCIS between two galvanized metal rings. The washed sorbent and membranes were also purchased from EST Labs. For monitoring in the Soufriere River, for each cage that contained three POCIS, one was PRC-spiked and the other two were purchased from EST Labs. For monitoring in Soufriere Bay, all three POCIS in each cage were spiked with the PRC. All field blank POCIS were also spiked with the PRC.

The data on the amounts of the target compounds adsorbed onto POCIS over the deployment period (i.e., ng/POCIS) can be used to estimate the time weighted average (TWA) concentrations of the pesticides in water (i.e., ng /L) using sampling rates previously determined in laboratory experiments (Rscal). The theory of passive sampling was described 
previously by Sultana et al. (2017), including the equation used for estimating the TWA concentrations in water $\left(\mathrm{C}_{\mathrm{w}}\right)$ :

$\mathrm{C}_{\mathrm{w}}=\mathrm{M}_{\mathrm{s}} / \mathrm{R}_{\mathrm{s}-\mathrm{cal}} \mathrm{t}$

where, $M_{s}$ is the mass of the target compound (ng) accumulated on the POCIS sorbent over the deployment period in days $(t)$ and $R s$-cal is the sampling rate expressed as the volume of water cleared of the target compound per day (i.e., L/d).

Rs-cal values for target compounds are listed in Supplementary Information in Table S2. The Rs-cal value for metformin was taken from Kim and Homan (2020) and the Rs-cal value for fluconazole was taken from Metcalfe et al. (2019). All other values are from Sultana and Metcalfe (submitted). These sampling rates were adjusted for the effects of field conditions on the uptake of the target compounds during deployment by calculating the rate of elimination of the PRC from spiked POCIS over the period of deployment. Parameters affecting sampling rates in the field (i.e., Rs-field) include water temperature, salinity, and turbulence, as well as biofouling of POCIS. The rate of elimination in the laboratory of the PRC, metoprolol-d 6 (i.e., -0.025 ), was previously determined by Sultana et al. (2017). Rates of elimination of metoprolol- $\mathrm{d}_{6}$ in spiked POCIS deployed in the field were determined by comparing the amounts of the PRC in the spiked field blanks to the amounts remaining in the spiked POCIS after retrieval. The theory for using PRCs to adjust the sampling rates was described previously by Sultana et al. (2017).

Analysis

\section{Total coliform and E. coli analysis}

Aliquots of grab samples were analyzed in triplicate for levels of total coliforms and $E$. coli bacteria using a membrane filtration Endo agar method, as described by the American Public Health Agency (APHA, 2012). Aliquots of $100 \mathrm{~mL}$ of undiluted water sample were vacuum-filtered through a sterile membrane filter (gridded, $0.45 \mu \mathrm{m}, 47 \mathrm{~mm}$ diameter) purchased from Millipore (Burlington, MA, USA). The filter was rinsed using buffered water and then placed in a petri plate on the surface of solidified Endo agar (Becton Dickson, Franklin Lakes, NJ, USA). The procedure was performed in triplicate for water samples obtained at each monitoring site. Petri plates were placed in a $35{ }^{\circ} \mathrm{C}$ incubator in an inverted position for $22 \mathrm{~h}$. A stereomicroscope with a fluorescent light source was used to count the number of coliform colonies on the filter. Coliform colonies were identified by their pink-red color and a metallic sheen. The atypical colonies were verified by using a swabbing technique. The verification media consisting of Lauryl Tryptose Broth and Brilliant Green Lactose Bile Broth, both purchased from Remel (San Diego, CA, USA), were incubated at $35^{\circ} \mathrm{C}$ for $24 \mathrm{~h}$ and observed for gas production and bacterial growth for confirmation of total coliforms.

For analysis of $E$ coli, buffered water and m-TEC agar culture media (Becton Dickson) were prepared. A urea substrate medium (Remel) was also prepared by adding reagents to $100-\mathrm{mL}$ reagent-grade water adjusted to $\mathrm{pH} 5.0 \pm 0.2$. Aliquots of $10 \mathrm{~mL}$ of the undiluted water samples were vacuum-filtered through a sterile membrane filter (gridded, $0.45 \mu \mathrm{m}$, $47 \mathrm{~mm}$ diameter) purchased from Millipore. Filters were then placed onto the agar surface in petri plates and the plates were incubated at $35{ }^{\circ} \mathrm{C}$ for $2 \mathrm{~h}$, then incubated at $44.5{ }^{\circ} \mathrm{C}$ for $22 \mathrm{~h}$. Plates were then removed from the incubator and placed onto an absorbent pad in the petri plate, saturated with the urea substrate. After $20 \mathrm{~min}$ of incubation in the urea substrate, the number of $E$. coli colonies was enumerated by light microscopy. The E. coli colonies were identified by color as yellow and yellowish green to brownish yellow.

\section{Analysis of chemical indicators}

Frozen grab samples were thawed and filtered through 1.0- $\mu \mathrm{m}$ glass fiber filters purchased from Millipore (Etobicoke, ON, Canada). Aliquots of $100 \mathrm{~mL}$ of the filtered samples, as well as procedural blanks of $100 \mathrm{~mL}$ of milliQ water, were extracted using both Oasis ${ }^{\circledR}$ MCX cation exchange cartridges and Oasis ${ }^{\circledR}$ MAX anion exchange cartridges according to methods previously described by $\mathrm{Li}$ et al. (2010) and Metcalfe et al. (2014), respectively. The solid phase extraction (SPE) cartridges were purchased from Waters (Milford, MA, USA). Prior to extraction, all samples were spiked with stable isotope-labeled surrogates of the target analytes purchased from CDN Isotopes (Pointe-Claire, 
QC, Canada) or Cambridge Isotopes (Andover, MA, USA) as internal standards. These surrogate compounds are listed in Supplementary Information in Table S1. After extraction, the sample volume was reduced to approximately $2 \mathrm{~mL}$ using a rotary evaporator and further reduced in volume to $0.4 \mathrm{~mL}$ using a vacuum centrifuge system.

Methods for extraction of the POCIS were described previously by Metcalfe et al. (2014). Procedural blanks and field blanks were extracted with the POCIS that were deployed in the field. Briefly, POCIS were dismantled and the sorbent was removed and transferred to a glass column previously filled with a layer of granular sodium sulfate. Solutions containing stable isotope surrogates of all target analytes were added to sorbent in the column before extraction. Acebutalol-d5 was also added to the sorbent from PRC-spiked POCIS as an internal standard for the analysis of the PRC. The sorbent in the column was extracted by eluting with $200 \mathrm{~mL}$ of methanol. The sample volume was reduced to approximately $2 \mathrm{~mL}$ using a rotary evaporator and further reduced to a $0.4-\mathrm{mL}$ volume using a vacuum centrifuge system.

All extracts prepared from grab samples and POCIS were analyzed by liquid chromatography with tandem mass spectrometry (LC-MS/MS) using a QTrap 5500 mass spectrometer coupled with an Agilent 1100 Series HPLC separation system purchased from ABS Sciex (Concord, ON, Canada) using methods previously described by Metcalfe et al. (2014). A Genesis C18 column ( $150 \mathrm{~mm}, 2.1 \mathrm{~mm}$ ID, $4 \mu \mathrm{m}$ particle size) purchased from Chromatography Specialties (Brockville, ON, Canada) with a guard column $(10 \mathrm{~mm} \times 2.1 \mathrm{~mm}$ ID) was used for chromatographic separations. The MS/MS instrument was operated in both positive and negative ion mode to identify the transitions of basic/neutral compounds and acidic compounds, respectively. Ion transitions for Multiple Reaction Monitoring (MRM) of target analytes and internal standards are summarized in Supplemental Information in Table S1. Responses to internal standards were used to correct for recoveries and the effects of the sample matrix on ionization efficiency. Data were acquired and processed using Analyst Software (ABS Sciex), version 1.6.2. Standards of the target analytes were used to generate a 9-point calibration curve. Linear regressions were generated for calibration curves. $R^{2}$ values for all analytes were above 0.96. Limits of detection (LOD) and limits of quantification (LOQ) for all analytes are listed in Supplementary Information (Table S1).

\section{Analysis of bacteroidales 16S rRNA}

Quantitative polymerase chain reaction (qPCR) assays using Bacteroidales 16S rRNA genetic markers were used to determine whether fecal bacteria originated from either human, bovine, or other warmblooded animals (i.e., BacHuman, BacBovine, and BacGeneral) using a protocol previously described by Lee et al. (2010). Briefly, aliquots of 18 water samples $(250 \mathrm{~mL})$ barcoded by Ontario Public Health were filtered under partial vacuum through 47-mm, $0.4-\mu \mathrm{m}$ polycarbonate filters purchased from Millipore. Prior to qPCR analysis, samples were thawed and any cells trapped on the filter were lysed with the addition of $2 \mathrm{~mL}$ of NucliSENS® EasyMAG® lysis buffer (bioMérieux, St-Laurent, QC, Canada), followed by incubation at $37^{\circ} \mathrm{C}$ for $1 \mathrm{~h}$ on a rolling drum $(0.2-0.3 \mathrm{rpm})$. DNA was purified and concentrated from the lysate with $100 \mu \mathrm{L}$ of EasyMAG magsil® beads (bioMérieux), using the Generic 2.0.1 protocol with the NucliSENS ${ }^{\mathrm{TM}}$ easyMAG automated nucleic acid purification system (bioMérieux) and eluted in $100 \mu \mathrm{L}$ of EasyMAG Extraction Buffer \# 3 (bioMérieux). Extracted DNA $(10 \mu \mathrm{L})$ was added to $15 \mu \mathrm{L}$ of the respective microbial source tracking assay mastermix (Human, Bovine, or General), as previously described by Lee et al. (2010). Analysis by qPCR was performed using the ViiA7TM Real-Time PCR System supplied by Applied Biosystems (Waltham, MA, USA). Results were reported as number of microbial cells per $100 \mathrm{ml}$ of water using the average gene copy number of 5.5 gene copies per microbial cell.

\section{Statistical analysis}

Data were analyzed statistically using $\mathrm{R}$ Studio version 1.1.463. Spearman's correlation analysis (nonparametric test) and multiple linear regressions were performed to determine relationships between sucralose and caffeine and fecal indicator microorganisms, where caffeine and sucralose were the predictor or independent $(\mathrm{x})$ variables and fecal indicator microorganisms were the actual or dependent (y) variables. The threshold for statistical significance was $p<0.05$. 


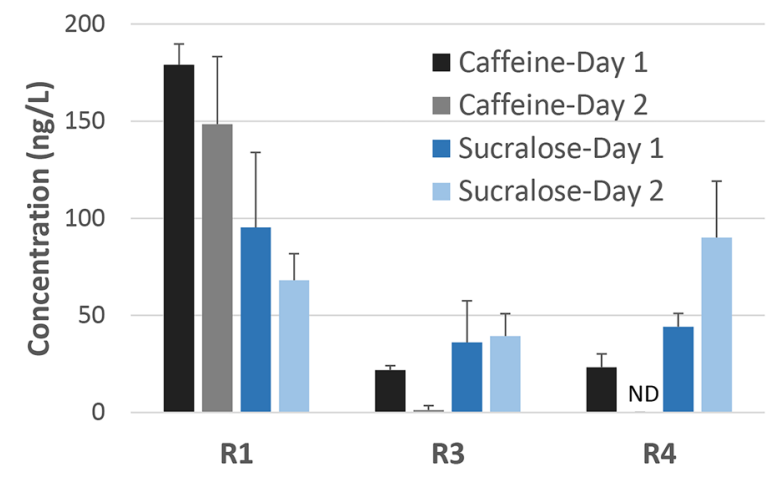

Fig. 2 Mean $(n=3 ; \pm \mathrm{SD})$ concentrations $(\mathrm{ng} / \mathrm{L})$ of caffeine and sucralose detected in grab samples collected at three sites in the Soufriere River in 2018 on July 4 (day 1) and July 17 (day 2). ND, not detected

\section{Results}

Microbial source tracking in the Soufriere River

In grab samples collected in the Soufriere River watershed on July 4th and 17th, 2018, sucralose and caffeine were detected at all three monitoring sites (Fig. 2). Mean caffeine concentrations detected in grab samples at R1 were as high as $179 \mathrm{ng} / \mathrm{L}$. The highest mean concentration of sucralose of $95 \mathrm{ng} / \mathrm{L}$ was detected in the grab sample collected on July 4 at site R1, but the mean sucralose concentration was also elevated at site R4 in a sample collected on July 17th, at a mean concentration of $90 \mathrm{ng} / \mathrm{L}$ (Fig. 2). The pharmaceutical, fluconazole, was also detected at a mean concentration of $3 \mathrm{ng} / \mathrm{L}$ in a single sample collected on July 4 at site R1. High temporal variations are expected in grab samples, as they represent a "snapshot" in time. POCIS samplers provide an estimate of the time weighted average concentrations over the 2-week deployment period.

Mean TWA concentrations of sucralose, caffeine, and fluconazole estimated from POCIS are shown in Table 1. Caffeine and sucralose were present at all five monitoring sites, but the estimated concentration of caffeine was highest at site R1 at a mean TWA concentration of $493 \mathrm{ng} / \mathrm{L}$. Estimated TWA concentrations of sucralose were all lower than $30 \mathrm{ng} / \mathrm{L}$, but levels were relatively consistent across monitoring sites. Fluconazole was also detected at trace amounts in POCIS deployed at all monitoring sites, with the highest estimated mean TWA concentration
Table 1 Mean $(n=3 ; \pm \mathrm{SD})$ TWA concentrations $(\mathrm{ng} / \mathrm{L})$ of sucralose, caffeine, and fluconazole estimated from POCIS deployed over the period from July 4 to 17,2018 at 5 monitoring sites in the Soufriere River

\begin{tabular}{lcll}
\hline Site & Caffeine & Sucralose & Fluconazole \\
\hline R1 & $492.9 \pm 131.0$ & $29.2 \pm 15.7$ & $0.81 \pm 0.24$ \\
R2 & $62.6 \pm 10.4$ & $17.1 \pm 9.9$ & $0.20 \pm 0.04$ \\
R3 & $16.9 \pm 2.8$ & $15.9 \pm 1.3$ & $0.15 \pm 0.02$ \\
R4 & $55.0 \pm 4.2$ & $11.4 \pm 4.4$ & $0.10 \pm 0.01$ \\
RP & $3.5 \pm 6.1$ & $17.0 \pm 8.9$ & $0.08 \pm<0.01$ \\
\hline
\end{tabular}

of $0.8 \mathrm{ng} / \mathrm{L}$ at site R1 (Table 1). There was generally good agreement between the concentrations estimated from POCIS deployed at sites R1, R3, and R4 and the concentrations measured in grab samples collected at these sites, although the mean TWA concentrations of caffeine estimated from POCIS deployed at R1 were higher, and the mean TWA concentrations of sucralose estimated from POCIS deployed at R3 and R4 were lower, relative to the concentrations determined in the corresponding grab samples.

Table 2 summarizes data on counts of total coliforms and $E$. coli determined from grab samples collected in triplicate at sites R1, R3, and R4 in the Soufriere River on July 4th and 17 th. These data indicate that the highest levels of fecal coliforms and $E$. coli were present in grab samples collected at site R1 at a location within the town of Soufriere. However, these indicator bacteria were detected at the two other locations in the watershed, including the site closest to the headwaters of the river (i.e., site R4). Data for the genetic biomarkers of human, bovine, and general sources in these samples are also summarized in Table 2. Numbers of Bacteroidales bacteria were also highest in grab samples collected at site R1, but once again, these fecal bacteria were also detected at the other two sites in the watershed. In the samples collected on both days, the majority of Bacteroidales fecal bacteria present in all grab samples were from sources other than human or bovine feces (Table 2). BacGeneral assays provide a value of the total Bacteroidales bacterial load that exists in the sample. The BacHuman and BacBovine assays are a subset of the BacGeneral population.

To assess the potential for using caffeine and sucralose as chemical indicators of wastewater contamination, relationships with fecal indicator bacteria were explored with data generated from individual 
Table 2 Mean counts of colonies of fecal coliform bacteria and $E$. coli $(\mathrm{CFU} / 100 \mathrm{~mL})$ and mean numbers of cells expressing Bacteroidales 16S rRNA (cells $/ 100 \mathrm{~mL}$ ) detected in grab samples ( $n=3$ per site) collected in 2018 on July 4 (day 1) and
July 17 (day 2) at three monitoring sites along the Soufriere River. BacHuman, human-specific Bacteroidales; BacBovine, bovine-specific Bacteroidales; BacGeneral, Bacteroidales from warm-blooded animals other than humans and bovine species

\begin{tabular}{|c|c|c|c|c|c|c|c|c|c|c|}
\hline \multirow[t]{2}{*}{ Site } & \multicolumn{2}{|c|}{$\begin{array}{l}\text { Total coliforms } \\
\text { CFU } / 100 \mathrm{ml}\end{array}$} & \multicolumn{2}{|c|}{$\begin{array}{l}\text { E. coli } \\
\text { CFU/100 ml }\end{array}$} & \multicolumn{2}{|c|}{$\begin{array}{l}\text { BacHuman } \\
\text { cells } / \mathbf{1 0 0 ~} \mathbf{~ l}\end{array}$} & \multicolumn{2}{|c|}{$\begin{array}{l}\text { BacBovine } \\
\text { cells } / 100 \mathrm{ml}\end{array}$} & \multicolumn{2}{|c|}{$\begin{array}{l}\text { BacGeneral } \\
\text { cells } / 100 \mathrm{ml}\end{array}$} \\
\hline & Day 1 & Day 2 & Day 1 & Day 2 & Day 1 & Day 2 & Day 1 & Day 2 & Day 1 & Day 2 \\
\hline $\mathrm{R} 1$ & 2650 & 8417 & 610 & 2675 & 9524 & 14,118 & 899 & 1139 & 151661 & 204585 \\
\hline $\mathrm{R} 3$ & 1020 & 1068 & 605 & 60 & 158 & 775 & 49 & 101 & 2312 & 2480 \\
\hline $\mathrm{R} 4$ & 2627 & 1000 & 373 & 83 & 1215 & 786 & 163 & 173 & 9353 & 10068 \\
\hline
\end{tabular}

grab samples collected on each sampling date at R1, R3, and R4 (i.e., $n=9$ ). Goodness of fit was tested using the data for the levels of multiple microbiological indicators (e.g., E. coli, total coliforms, BacHuman) and the data on the concentrations of caffeine and sucralose using either single linear regression or multiple linear regression models. There was a good correlation $\left(R^{2}=0.79\right)$ between concentrations of caffeine and sucralose collectively and the levels of human-specific Bacteroidales (i.e., BacHuman) in samples collected on sampling day 1 (Fig. 3). This multiple linear regression relationship was statistically significant $(p<0.05 ; p=0.0089)$. Caffeine and sucralose collectively also demonstrated a relationship ( $p<0.05, p=0.0064)$ with total coliforms in water samples collected on sampling day 2 (Fig. 4). It should be noted that there was also a good correlation between the concentrations of caffeine alone and total coliforms on day $2\left(R^{2}=0.81\right)$ and this relationship was statistically significant $(p<0.05, p=0.0009)$. No statistically significant relationships were observed

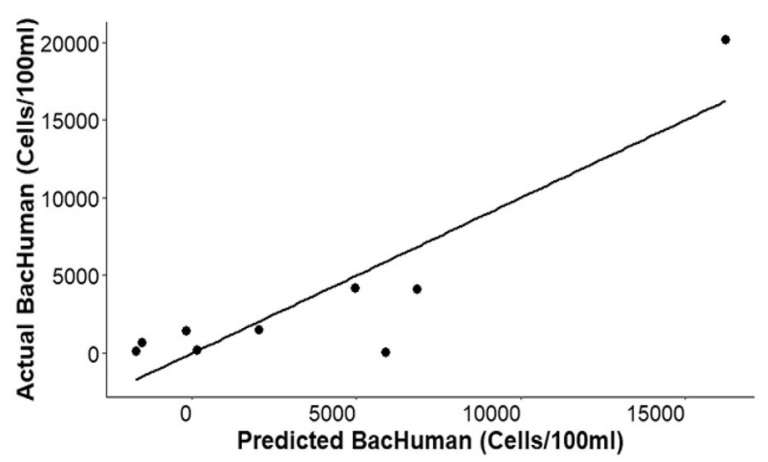

Fig. 3 Observed vs predicted regression scatterplots derived from a linear model with the equation $y=120.3$ (caffeine) -185.7 (sucralose) +5505.5; where $y$ is numbers of human-specific Bacteroidales (BacHuman) in cells $/ 100 \mathrm{ml}$ for water samples $(n=3$ per site) collected on sampling day 1 in the Soufriere River between E. coli and caffeine and sucralose using either single or multiple linear regression approaches.

Survey of microbial indicators in the Soufriere River and Soufriere Bay

Grab samples of coastal water collected from Soufriere Bay and surface waters collected from the Soufriere River over the period from February to May 2019 showed wide variations in counts of total coliforms and E. coli. Figure 5a shows counts of E. coli in samples collected from 10 sites in Soufriere Bay, and Fig. 5b shows E. coli counts in samples collected from 9 sites in the Soufriere River over the 12 dates of the survey period. Corresponding data for total coliform counts in the samples collected during this survey are illustrated in Fig. S2 in Supplementary Information.

E. coli data illustrated in Fig. 5 show that the highest counts in Soufriere Bay were observed in

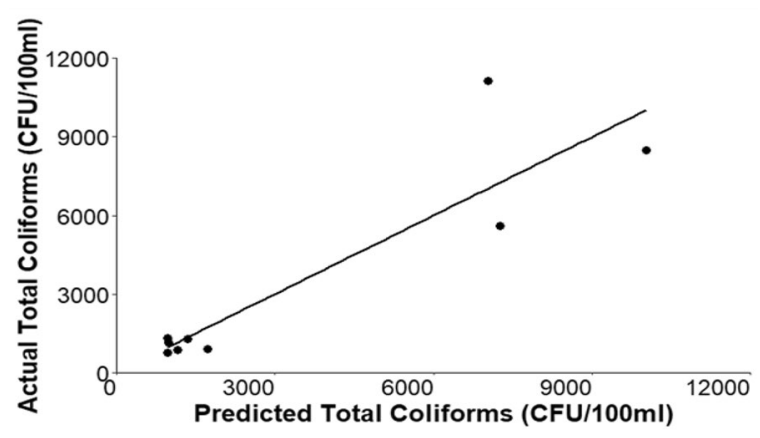

Fig. 4 Observed vs predicted regression scatterplots derived from a linear model with the equation $y=46.525$ (caffeine) +9.844 (sucralose) +525.237 ; where $y$ is total coliform counts in CFU/100 ml for water samples ( $n=3$ per site) collected on sampling day 2 in the Soufriere River 
Fig. 5 Counts (CFU/100 mL) of E. coli in water samples collected from A 10 sites in Soufriere

Bay, and $\mathbf{B} 9$ sites in the Soufriere River. Samples were collected over a survey period of 12 dates from February to May 2019
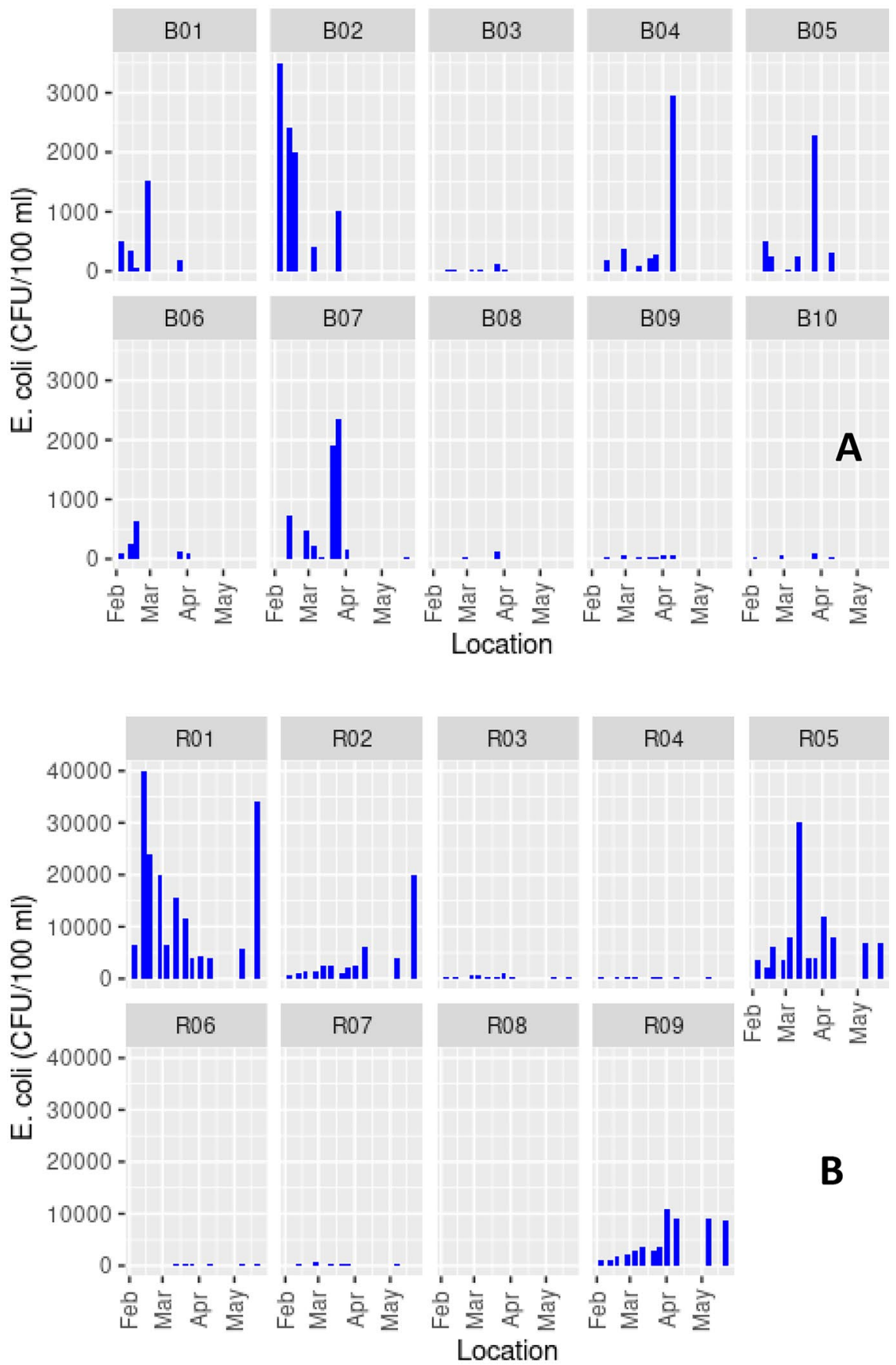

February in samples collected at site B02, but in March, the highest counts were observed in samples collected at sites B05 and B07, while in early April, the highest counts were observed in samples collected at site B04. All samples with high $E$. coli counts were from sites closest to the shoreline, with the exception of site B07. Sites B02 and B07 are located at inshore and offshore locations to the north of the discharge of the Soufriere River. E. coli counts in the Bay (Fig. 5a) were about an order of magnitude lower than $E$. coli counts observed in samples collected in the Soufriere River (Fig. 5b). 
Locations in the Soufriere River where the highest $E$. coli counts were observed were consistently at sites R01, R02, R05, and R09 (Fig. 5b). Sites R01 and R02 are located within the town of Soufriere (i.e., Palmiste Road and New Development Bridge, respectively), but sites R05 (i.e., FSJ Sportsground) and R09 (i.e., St. Phillip Bridge) are located on the Migny River branch of the Soufriere watershed close to the source waters in the upper ridges of the watershed. In February of 2019, there was a relatively consistent pattern between the dates that simultaneously showed high E. coli counts in the Bay and in the river at R01, but thereafter, dates with high counts in the river did not correlate with spikes in counts in the Bay, and vice versa (Fig. 5). Corresponding data on fecal coliforms also showed a lack of a correlation between dates when counts spiked in the Bay and dates when counts spiked in the river (Fig. S2).

Monitoring for chemical indicators in Soufriere Bay

Table 3 provides a summary of TWA concentrations of sucralose, caffeine, and fluconazole and other selected pharmaceuticals estimated from amounts of these compounds that accumulated in POCIS over 2 weeks of deployment at 5 sites in Soufriere Bay in October 2020. None of the target compounds were detected in the field blank POCIS, except for trace amounts of caffeine. These background amounts of caffeine were subtracted from amounts that accumulated on the POCIS deployed in the coastal zone. Caffeine and sucralose, as well as two non-prescription analgesics (i.e., acetaminophen, ibuprofen), were detected at all deployment sites except B3, with the highest estimated concentrations at sites B1 and B5 (Table 3). Data show that fluconazole was detected at a very low estimated TWA concentrations at station

Table 3 Mean $(n=3 ; \pm \mathrm{SD})$ TWA concentrations ( $\mathrm{ng} / \mathrm{L})$ of target analytes estimated from amounts of the compounds that accumulated on POCIS deployed at 5 monitoring sites in Sou-
B1 and was detected in amounts below the limit of quantitation (LOQ) at station B5 (Table 3). Estimated concentrations of sucralose in the Bay were comparable to concentrations of this artificial sweetener estimated from POCIS deployed in the Soufriere River, but concentrations of caffeine in the Bay were about an order of magnitude lower than maximum concentrations detected in the Soufriere River (Table 1). Metformin, which is a drug used to treat type- 2 diabetes, was also detected in POCIS deployed in the Bay at sites B1, B2, and B5 (Table 3).

\section{Discussion}

Results presented here are a compilation of data collected during three separate sampling campaigns conducted over the period between July 2018 and October 2020. The separate campaigns were necessary because of delays in securing project funding, and also because of interruptions to sampling logistics caused by the global pandemic. While it would have been optimal to collect the samples in Soufriere Bay and the Soufriere River watershed over the same timeframe, collectively, these data provide compelling evidence for tracking the sources of fecal contamination in the region.

Data show that levels of $E$. coli and total coliforms in water samples collected at several sites in the Soufriere River exceeded the water quality standards for St. Lucia. Guidelines for Recreational Water Quality for St. Lucia state that re-sampling should be conducted if $E$. coli levels in any water sample exceeds $400 \mathrm{CFU} / 100 \mathrm{ml}$ and this standard was exceeded in several samples. Levels of total coliforms and E. coli in many of the samples collected in Soufriere Bay in 2019 were comparable to levels of these indicator

friere Bay during October 2020. ND, not detected; $P$, present at concentrations $<$ LOQ

\begin{tabular}{lllllll}
\hline Site & Caffeine & Sucralose & Fluconazole & Ibuprofen & Acetaminophen & Metformin \\
\hline B1 & $120.4 \pm 5.2$ & $22.4 \pm 5.6$ & $0.1 \pm<0.1$ & $95.0 \pm 34.7$ & $16.8 \pm 11.4$ & $18.0 \pm 1.6$ \\
B2 & $8.6 \pm 3.2$ & $9.6 \pm 2.3$ & ND & $28.0 \pm 7.1$ & P & $3.3 \pm 1.5$ \\
B3 & ND & ND & ND & ND & ND & ND \\
B4 & $14.5 \pm 0.6$ & $2.0 \pm 1.0$ & ND & ND & $10.6 \pm 1.9$ & ND \\
B5 & $220.8 \pm 46.6$ & $43.6 \pm 10.2$ & P & $304.3 \pm 25.6$ & $252.0 \pm 42.0$ & $36.9 \pm 7.4$ \\
\hline
\end{tabular}


bacteria reported for polluted marine waters from other areas in the Caribbean (Gavio et al., 2010; Wade et al., 2015). The lack of correlations between spikes in the levels of indicator bacteria in the Soufriere River and Soufriere Bay may indicate that the Bay is impacted by other sources of microbiological contamination, in addition to discharges from the Soufriere River. An alternate explanation for the lack of correlations may be dilution in the Bay, sedimentation of bacteria associated with particulates, solar inactivation, or a combination of all these factors.

Correlations observed in samples collected from the Soufriere River between concentrations of sucralose and caffeine collectively and the numbers of human-specific Bacteroidales (BacHuman) cells are strong evidence that these two compounds that originate from foods and beverages are good chemical indicators of microbial contamination from human fecal matter. Caffeine has been used in several previous studies as an indicator of wastewater contamination from urban sources (Buerge et al., 2006; Daneshvar et al., 2012; Ferreira et al., 2005; Sauvé et al., 2012), as well as contamination from wastewater in coastal marine environments (Nödler et al., 2016). The artificial sweetener, sucralose, has also been recommended as a chemical indicator of contamination from wastewater, with the advantage that this compound is more persistent than caffeine in the aquatic environment (Spoelstra et al., 2013; Tollefsen et al., 2012). Other prescription and non-prescription pharmaceuticals detected in surface waters provide corroborating evidence of contamination from domestic sewage (Tran et al., 2015).

Bacteroidales host-specific genetic sequences have been widely used as markers of fecal pollution originating from warm-blooded animals, such as humans, bovine ruminants, pigs, and horses (Tran et al., 2015). Unfortunately, host-specific genetic markers are currently available for only a few animal species. In addition, there may be instability of host-specific genetic markers due to horizontal transfer of genes among species in close contact, such as humans and their pets, or humans and domestic animals (Tran et al., 2015). Notwithstanding the limitations of the use of Bacteroidales host-specific genetic markers of fecal contamination, data from the present study indicated that a large proportion of fecal bacteria present in the Soufriere watershed came from sources that are not human or bovine. Using the qPCR technique available for this study, it was not possible to identify the species of animals responsible for this fecal contamination, but it is known that goats, chickens, hogs, and horses are raised on farms within the watershed.

However, human fecal bacteria were also detected throughout the watershed, and especially at the R1 site located within the town limits of Soufriere. These data are consistent with the presence of caffeine and sucralose at sites throughout the watershed, which is an indicator of contamination from sewage or human fecal material. Overall, these data indicate that management options to reduce contamination in the watershed should include controls in the upper part of the watershed to reduce runoff of manure and direct access to the river by domestic animals. Controls are also needed throughout the watershed, but especially in the lower part, to reduce contamination from domestic sewage or fecal material of human origin. Overall, it appears that discharges from the Soufriere River are carrying fecal bacteria into Soufriere Bay that originate from both humans and domestic animals.

A priori, it was assumed that the highest concentrations of caffeine, sucralose, and pharmaceuticals estimated from POCIS deployments in Soufriere Bay would be detected at the sites closest to the discharge of the Soufriere River (i.e., sites B2 and B3). However, none of these chemical indicators were detected in the POCIS deployed at B3, located to the south of the river discharge. This may be because prevailing currents in this region are in a northwesterly direction (Wilson \& Johns, 1997), which would carry the plume from the river away from site B3. Some of the chemical indicators were detected at low estimated concentrations in POCIS deployed at site B2 to the north of the river discharge. It is also probable that there was incomplete mixing of the contaminated freshwater plume down to the depth in the Bay where the POCIS were deployed (i.e., $\sim 5 \mathrm{~m}$ ). The highest estimated concentrations of caffeine, sucralose, and pharmaceuticals were detected from POCIS deployed at site B1 (offshore of Hummingbird Beach) and site B5 (offshore of Baron's Drive). The presence of these two "hot spots" for chemical indicators indicates that there are sources within the town of Soufriere of contamination from sewage or fecal material of human origin.

As is typical of urban centers in other Caribbean islands, the population of the town of Soufriere is 
not connected to a centralized sewage collection and treatment system and instead, most of the population uses on-site wastewater treatment facilities such as septic tanks with soak away pits. However, according to the 2010 population and housing census report for St. Lucia, an estimated 30\% of the population of Soufriere is not linked to septic tanks and uses other means to dispose of fecal waste. In the report by CEHI (2006), the economically depressed area of Baron's Drive in the town of Soufriere was identified as an area where many households do not have septic tanks, and instead use pit latrines or even practice open defecation. Therefore, surface runoff, leakage from faulty septic systems and latrines, and direct disposal of fecal material into the Bay are the probable sources of the sucralose, caffeine, and other chemical indicators that were detected at the site near Baron's Drive at B5 in Soufriere Bay. The site near Hummingbird Beach at B1 is impacted by a storm drain that carries runoff from a beach park and the Palmiste settlement to the north of the town of Soufriere. This indicates that the high levels of fecal bacteria detected in Soufriere Bay are at least partially due to urban runoff and stormwater discharges in the region. It is noteworthy that heavy rains were experienced in the area in 2020 during the 2-week deployment period for POCIS in Soufriere Bay.

Overall, these data show that microbial contamination of the Soufriere River and Soufriere Bay originates from both humans and domestic animals. To reduce this contamination, steps are needed to control inputs of fecal material throughout the watershed and in the town of Soufriere. Recommendations on improvements for the management of domestic sewage in the town of Soufriere that were proposed by CEHI (2006) are still applicable. These recommendations included programs to improve the socioeconomic status of residents in the Baron's Drive section of Soufriere and over the short-term, to refurbish the communal sanitary facility in this area (CEHI, 2006). Also recommended were incentive programs to encourage citizens to enhance existing septic treatment systems, and installation of facilities for treating effluents from the Fishing Complex (CEHI, 2006). Less costly approaches could include construction of stormwater retention ponds to intercept polluted runoff and the establishment of treatment wetlands to treat stormwater, gray water, and/or septic overflow. This would be especially beneficial for treatment of stormwater discharged into Soufriere Bay through a drain at Hummingbird Beach. Treatment wetlands have been shown to be a source of community income through the cultivation of ornamental flowers (Belmont et al., 2017).

Measures are also needed to manage contamination of the Soufriere River by microorganisms originating from animal manure. These measures will have the added benefit of reducing flooding during extreme weather events. Riparian zones should be protected during the construction of new roads and homes in the watershed or restored in those areas where they have been previously removed. Storm water retention ponds should be constructed to retain pollutants and reduce flooding during storms events. Fencing or other barriers should be installed along the river to discourage access by domestic animals.

Chronic problems related to wastewater management and sanitation in the Soufriere region of St. Lucia are a microcosm of the challenges faced by Caribbean island nations, as well as SIDS around the globe in meeting the targets for Sustainable Development Goal 6 for expanded and improved treatment of domestic wastewater and providing universal access to sanitation facilities.

Acknowledgements The authors thank Brenda Seaborn, Cassandra Johannessen, and Erin Hayward for their technical help with the project. The authors would also like to thank the following individuals from the town of Soufriere who helped with the sampling campaign in the Soufriere River: Nadia Cazaubon of Caribbean SEA/Waterways, Michael Bobb of Soufriere Marine Management Association (SMMA), Alvin Francis, Lester Jean, Kate McKenzie, David DuBoulay, Mathew Nelson, Pius Faustin, Seth Faustin, Ashton Alexander, and Martinus Lovence.

Funding This work was supported by financial and in-kind contributions from various agencies, including the Integrating Water, Land and Ecosystems Management in Caribbean Small Island Developing States program of the Global Environmental Facility (GEF-IWEco), the Caribbean Public Health Agency (CARPHA), and the Deutsche Gesellschaft für Internationale Zusammenarbeit (GIZ). Marsha Serville-Tertullien received support from a graduate scholarship provided by the Trillium Foundation of Ontario and a graduate stipend from the CREATE H2O program funded by the Natural Sciences and Engineering Research Program (NSERC) of Canada.

Availability of data and materials Data generated and analyzed during the current study are available upon reasonable request from the corresponding author. 


\section{Declarations}

Conflict of interest The authors declare no competing interests.

\section{References}

APHA. (2012). Standard methods for water and wastewater examination. American Public Health Association.

Bégin, C., Brooks, G., Larson, R. A., Dragićević, S., Scharrón, C. E. R., \& Côté, I. M. (2014). Increased sediment loads over coral reefs in Saint Lucia in relation to land use change in contributing watersheds. Ocean \& Coastal Management, 95, 35-45.

Belmont, M. A., Cantellano, E., \& Ramirez-Mendoza, N. (2017). Growing ornamental flowers and fish in indigenous communities in Mexico: An incentive model for pollution abatement using constructed wetlands. In $\mathrm{N}$. Nagabhatla \& C. D. Metcalfe (Eds.), Multifunctional Wetlands: Pollution Abatement and Other Ecological Services from Natural and Constructed Wetlands, 234-247. Springer.

Bermudez, M., \& Hazen, T. C. (1988). Phenotypic and genotypic comparison of Escherichia coli from pristine tropical waters. Applied Environmental Microbiology, 54, 979-983.

Buerge, I. J., Poiger, T., Müller, M. D., \& Buser, H.-R. (2006). Combined sewer overflows to surface waters detected by the anthropogenic marker caffeine. Environmental Science \& Technology, 40, 4096-4102.

Cashman, A. (2013). Water security and services in the Caribbean. Water, 5, 1-17.

CEHI. (2006). Assessment of the infrastructure for improved wastewater management in Soufriere. Caribbean Environmental Health Institute, Castries, St. Lucia.

Daneshvar, A., Aboulfadl, K., Viglino, L., Broseus, R., Sauvé, S., \& Madoux-Humery, A. S. (2012). Evaluating pharmaceuticals and caffeine as indicators of fecal contamination in drinking water sources of the Greater Montreal region. Chemosphere, 88, 131-139.

ECLAC. (2019). Quadrennial report on regional progress and challenges in relation to the 2030 Agenda for Sustainable Development in Latin America and the Caribbean. Economic Commission for Latin America and the Caribbean, Santiago, Chile.

Ferreira, A. P., de Lourdes, C., \& da Cunha, N. (2005). Anthropic pollution in aquatic environment: Development of a caffeine indicator. International Journal of Environmental Health Research, 15, 303-311.

Gavio, B., Palmer-Cantillo, S., \& Mancera, J. E. (2010). Historical analysis (2000-2005) of the coastal water quality in San Andrés Island, SeaFlower Biosphere Reserve, Caribbean Colombia. Marine Pollution Bulletin, 60, 1018-1020.

Kim, H., \& Homan, M. (2020). Evaluation of pharmaceuticals and personal care products in drinking water originating from Lake Erie. Journal of Great Lakes Research, 46, 1321-1330.
Li, H., Helm, P. A., \& Metcalfe, C. D. (2010). Sampling in the Great Lakes for pharmaceuticals, personal care products, and endocrine-disrupting substances using the passive polar organic chemical integrative sampler. Environmental Toxicology and Chemistry, 29, 751-762.

Lee, D.-Y., Weir, S., Lee, H., \& Trevors, J. (2010). Quantitative identification of fecal water pollution sources by TaqMan real-time PCR assays using Bacteroidales 16S rRNA genetic markers. Applied Microbiology and Biotechnology, 88, 1373-1383.

Malik, O., Hsu, A., Johnson, L. A., \& de Sherbinin, A. (2015). A global indicator of wastewater treatment to inform the Sustainable Development Goals (SDGs). Environmental Science and Policy, 48, 172-185.

Metcalfe, C. D., Helm, P. A., Paterson, G., Kaltenecker, G., Murray, C., Nowierski, M., \& Sultana, T. (2019). Pesticides related to land use in the watersheds in the Great Lakes basin. Science of the Total Environment, 648, 681-692.

Metcalfe, C., Hoque, M. E., Sultana, T., Murray, C., Helm, P., \& Kleywegt, S. (2014). Monitoring for contaminants of emerging concern in drinking water using POCIS passive samplers. Environmental Science: Processes \& Impacts, $16,473-481$.

Nödler, K., Tsakiri, M., Aloupi, M., Gatidou, G., Stasinaki, A. S., \& Licha, T. (2016). Evaluation of polar organic micropollutants as indicators for wastewater-related coastal water quality impairment. Environmental Pollution, 211, 282-290.

PAHO. (2001). Regional report on the evaluation 2000 in the region of the Americas: Water supply and sanitation, current status and prospects, Pan-American Health Organization, Washington, D.C., USA.

Pittman, J., Armitage, D., Alexander, S., Campbell, D., \& Alleyne, M. (2015). Governance fit for climate change in a Caribbean coastal-marine context. Marine Policy, 51, 486-498.

Saint Lucia Forests and Lands Resources Department. (2015). Saint Lucia forests and lands resources department strategy 2015-2025, Union, Saint Lucia.

Sauvé, S., Aboulfadl, K., Dorner, S., Payment, P., Deschamps, G., \& Prévost, M. (2012). Fecal coliforms, caffeine and carbamazepine in stormwater collection systems in a large urban area. Chemosphere, 86, 118-123.

Spoelstra, J., Schiff, S. L., Brown, S. J. (2013). Artificial sweeteners in a large Canadian river reflect human consumption in the watershed. PLoS One, 8, e82706.

Sultana, T., Metcalfe, C. D. (submitted). Calibration and field validation of POCIS passive samplers for tracking artificial sweeteners as indicators of municipal wastewater contamination in surface waters. Environmental Monitoring and Assessment.

Sultana, T., Murray, C., Hoque, M. E., \& Metcalfe, C. D. (2017). Monitoring contaminants of emerging concern from tertiary treatment plants using passive sampling modelled with Performance Reference Compounds. Environmental Monitoring and Assessment, 189, 1-19.

Tran, N. H., Yew-Hoong Gin, K., \& Ngoc, H. H. (2015). Fecal pollution source tracking toolbox for identification, evaluation and characterization of fecal contamination in 
receiving urban surface waters and groundwater. Science of the Total Environment, 538, 38-57.

Tollefsen, K. E., Nizzetto, L., \& Huggett, D. B. (2012). Presence, fate and effects of the intense sweetener sucralose in the aquatic environment. Science of the Total Environment, 438, 510-516.

UNEP-CEP. (2010). Regional sectoral overview of wastewater management in the wider Caribbean Region: Situational analysis. CEP Technical Report \#66. United Nations Environmental Programme - Caribbean Environmental Programme. Kingston, Jamaica.

Wade, C., Otero, E., Poon-Kwong, B., Rozier, R., \& Bachoon, D. (2015). Detection of human-derived fecal contamination in Puerto Rico using carbamazepine, HF183 Bacteroides, and fecal indicator bacteria. Marine Pollution Bulletin, 101, 872-877.

Wilson, W. D., \& Johns, W. E. (1997). Velocity structure and transport in the Windward Islands passages. Deep-Sea Research, 44, 487-520.

Publisher's Note Springer Nature remains neutral with regard to jurisdictional claims in published maps and institutional affiliations. 